INTERNATIONAL JOURNAL OF

ORGANIZATIONAL LEADERSHIP

WWW.CIKD.CA

\title{
The Role of Organizational Leadership in Customer Loyalty through Managing Conflict between Employees and Customers
}

\author{
Samad Aali', Abdulhamid Ibrahimi2*, Vahid Reza Mirabi ${ }^{3}$, Shahram Zare \\ ${ }^{1}$ Department of Business Management, Qeshm International Branch, Islamic Azad University, Qeshm, Iran \\ ${ }^{2 *}$ Faculty of Management, Allameh Tabatabai University, Tehran, Iran \\ ${ }^{3}$ Department of Management, Central Tehran Branch, Islamic Azad University, Tehran, Iran \\ ${ }^{4}$ Department of Social Medicine, Hormozgan University of Medical Sciences, Bandar Abbas, Iran
}

\begin{tabular}{l} 
Keywords: \\
Conflict management, Trust, \\
Commitment, Customer \\
satisfaction, Customer loyalty \\
\hline Received \\
29 December 2019 \\
Received in revised form \\
25 January 2020 \\
Accepted \\
25 February 2020 \\
\hline
\end{tabular}

Correspondence:

ebrahimy39@yahoo.com

\begin{abstract}
The trends in the business world such as the transition to a service-based economy and the development of ICTs have significantly increased the importance of relationship-based loyalty for firms. In line with these changes, a long-term relationship with the customer has become a vital strategy in banking industry. The purpose of this paper is to show the role of organizational leadership in customer loyalty by examining the association between managing conflict, relationship quality and customer loyalty in banking services. In this respect, Agriculture bank of Iran was selected as the target population of the suggested theoretical model of this study and 417 customers of the bank have participated as the statistical samples to achieve the goals of this paper. Samples were selected using simple random sampling and research hypotheses were tested using structural modeling technique and AMOS software. The results showed that the managing conflict has an indirect and positive effect on customer loyalty through relationship quality. Furthermore, the managing conflict had a direct and positive effect on Trust, commitment, and customer satisfaction. In addition, an increase in trust, commitment and customer satisfaction with the bank led to increases in customer loyalty. Findings revealed that the organizational leadership by managing conflict between employees and customers can improve the quality of the customer-company relationship and lead to customer loyalty.
\end{abstract}


Trends in business world, including the transition to a service-based economy, the development of ICTs, and increasing global competition has led to increasing the importance and attractiveness of loyalty based on the relationship in comparison with other mix marketing. At the same time, some of these trends have simultaneously increased customer expectations to receive unique features such as reducing the conflict, the higher level of trust and greater flexibility in the exchange-based relationship. This situation often encourages both buyers and sellers to build closer relationships in transactions (Palmatier, 2009). Creating a closer relationship increases the likelihood of conflict. Conflicts in relationships are predictable and inaccurate perceptions. Change of values and fairness play an important role in causing conflict. The organization leadership ability to manage conflict is vital to maintain buyers (Dwyer \& Oh, 1987).

The leader of organization plays a key role in conflict management by creating the right organizational climate. A superior approach to conflict management is to actively plan and execute the conflict, which involves identifying the conflict, resolving the conflict before it is revealed, preventing potential conflict and blocking it. These efforts will lead to better customer relationships and customer loyalty (Ndubisi, 2007). Conflict management is an important tool for relationship building. Although it is difficult to achieve non-conflict transactions in the service industry and especially in banking, it is important to provide effective solutions to the conflict or to have a proper mechanism for solving the problems. In this regard, the role of the leader of organization is very important, if not carefully managed, can lead to the loss of a customer (Salim, 2011).

Today in banking industry, long-term relationship with the customer is a critical strategy. Banks must build a long-term and profitable relationship with their customers in order to survive in the current competitive banking environment (Clemes, Mollenkopf, \& Burn, 2010). In recent years, Iran's financial services sector, especially the banking industry, has become more competitive due to the emergence of new technologies, the relative similarity of services, and the presence of private sector competitors. Therefore, banks need to establish a close and secure relationship with their customers in order to differentiate and survive in competition. It is obvious that maintaining and developing a long-term relationship does not occur spontaneously and it requires adopting appropriate ways for conflict management. Therefore, a comprehensive study is needed to better understand how organizational leaders can enhance customer loyalty to an organization through conflict management. The present article seeks such a study and is organized as follows. First, we describe the concept of conflict management, relationship quality and customer loyalty and the relationships between them within the literature. Second, we examine the effects of conflict management on the quality of the relationship and customer loyalty. Finally, we discuss the findings and provide managerial implications and directions for future research. 


\section{Theoretical Background}

\section{Conflict Management}

Conflict management is the process of solving a problem. The best way to resolve a conflict is to provide a constructive solution to the conflict. Because in this way, the solution satisfies all parties involved in the conflict and they feel that their interests have been derived from conflict resolution. (Deutsch, 2001).

Conflict management reflects the ability of seller for avoiding potential conflict, solving conflicts before they create problems, speaking freely and presented appropriate solutions when problem occurs. Conflict management requires the cooperative behavior of the parties to the transaction (Sweeney \& Pierce, 2004). In service industries particularly in the banking achieving exchange is hard without conflict and presenting effective solutions to conflict or having an appropriate mechanism for solving problems are very important (Lattimore, 2011).

\section{Relationship Quality}

Creating a strong, long-term relationship with customers is one of the essential elements in marketing. Not only creating a relationship but also having it maintained and extended is among the necessities which make customers buy more, pay more, and feel more emotionally (Rafiq, Fulford, \& Lu, 2013). Relationship quality can be defined as a multi-dimensional construct that is related to a customer's assessment of his/her overall relationship with a service provider at a specific time based on all previous interactions with that provider (Keating, Alpert, Kriz, \& Quazi, 2011).

Previous studies have presented convincing evidence about the relationship between relationship quality as a higher level construct including trust, satisfaction, and commitment as well as the relationship between each dimension of the relationship quality and loyalty (Bilgihan \& Bujisic, 2014; Caceres \& Paparoidamis, 2007; De Wulf, Odekerken-Schroder, \& Iacobucci , 2001; Fang, Shao, \& Wen, 2016; Kim, Lee, \& Yoo , 2006; Naoui \& Zaiem, 2010; Nusair, Bilgihan, Okumus, \& Cobanoglu, 2013; Palmatier, 2008; Papassapa \& Miller, 2007). Thus, in the present study, we have conceptualized online relationship quality by using the three key dimensions of trust, satisfaction, and commitment.

\section{Commitment}

Commitment is a stable desire to maintain the value of communication, meaning that a higher level of commitment creates a successful, profitable, and mutually satisfactory relationship (Chung \& Shin, 2010). Morgan and Hunt (1994) defined commitment as "an exchange partner believing that an ongoing relationship with another is so important as to warrant maximum efforts at maintaining it; that is, the committed party believes the relationship endures indefinitely". According to Luarn and Lin (2003), commitment is "a consumer's psychological attachment to a service that develops before a customer would be able to determine that their repeat purchase behavior was derived from a sense of loyalty" (Elbeltagi \& Agag, 2016). 


\section{Satisfaction}

Customer satisfaction plays a very important role in competitive environments. Chang, Wang, and Yang, (2009) defined customers' satisfaction as "the psychological reaction of the customer with respect to his or her prior experience with the comparison between expected and perceived performance". Satisfaction as a tool for measuring and evaluating the relational quality is viewed as an affective position in which the cognitive aspect is not considered. This can be explained better when we focus more precisely on the affective-based components of satisfaction and find it more important than the cognitive ones (Berry \& Parasuraman, 1991).

\section{Trust}

Morgan and Hunt (1994) defined trust as confidence in exchange partner. According to Doney and Cannon (1997), trust is "the perceived credibility and benevolence of a target". Arcand, Promtep, Brun, and Rajaobelina (2017) believe that trust is described as the tendency to depend on another entity (such as the service provider) in which the customer trusts the service provider and believes that the service provider works in a predictable way and will always act in a trustworthy and honest manner.

Many researchers claim that trust is one of the most important factors in determining consumers' initial and continued use of banking services (Lichtenstein \& Williamson, 2006; Rexha, Kingshott, \& Aw, 2003; Suh \& Han, 2002). Therefore, behind the quality of the relationship, trust represents one of the most important prerequisites for success in commerce and many studies confirm that trust is an essential factor in initiating and developing exchanges and relationships (Grabner-Krauter \& Kaluscha 2003; Hoffman, Novak, \& Peralta, 1999; Palvia, 2009).

\section{Loyalty}

Loyalty means a deep commitment to repurchase or support a product or service of interest that, in spite of the situational impact and competitor marketing efforts, leads to a repeat purchase of a brand (Birjandi, Gholami, \& Haghighi, 2018). Loyalty plays an important role in the survival and development of commerce (Chen, 2012) as it is an important motivation to maintain contact with the organization (Rafiq et al., 2013). Customer loyalty to a bank refers to a customer's intention to revisit the bank and consider the reuse of a given service in the future (Amin, 2016). Therefore, it can be said that maintaining existing customers and strengthening their loyalty are crucial tasks for service providers seeking to gain competitive advantage (Chen \& Wang, 2016) as it is very difficult to obtain loyal customers on the Internet (Chang \& Wang, 2011).

\section{Hypothesis Development}

\section{Conflict Management and Relationship Quality}

Conflict always arises during the relationship and conflict management which is essential to maintain the relationship. Yavas, Ennew, and Palmer (2004) found an indirect significant relationship between conflict management and customer loyalty through trust and perceived relationship quality. Naoui and Zaiem (2010) found that resolving conflicts between company 
employees and customers leads to improved relationship quality. Yang and Capel (2011) also showed that in the Malaysian and New Zealand banking industry, conflict management can improve bank-customer relationships and lead to customer commitment, trust, and satisfaction with the bank.

Ndubisi (2007) confirms positive effects of conflict management on the relationship quality in the banking industry in Malaysia. Lattimore (2011) found similar results in the banking industry in Canada and U.S. and suggested that the conflict management causes the increase of customer commitment, customer trust and finally customer satisfaction to the bank. We therefore propose following hypotheses:

\section{H1. Conflict management has a positive effect on Commitment to banking services. \\ H2. Conflict management has a positive effect on Trust to banking services. \\ H3. Conflict management has a positive effect on Satisfaction with banking services.}

\section{Trust and Loyalty}

Yamagishi and Yamagishi (1994) argued that trust "plays the role of a booster rocket that helps one to take off the secure ground of committed relationships". It can also be said that trust is a determinant factor in cyberspace as it helps maintain customers and develop long-term relationships with them (Sahney, Ghosh, \& Shrivastava, 2013). That is, when present, trust stimulates new transactions, while its absence acts as a barrier against new transactions. Moreover, trust plays a main role in determining the consumer's satisfaction, perceived usefulness of the website, intention to buy, and loyalty (Pengnate \& Sarathy, 2017). We therefore propose:

\section{H4: Trust has a positive effect on loyalty in banking services.}

\section{Trust and Commitment}

Although trust, commitment, and satisfaction are considered the dimensions of relationship quality, review of the related literature indicates that there is also an interrelation among these dimensions (Cater \& Zabkar, 2009; Geyskens, Steenkamp, Scheer, \& Kumar, 1996; Morgan \& Hunt, 1994). Trust is the foundation of long-term relationships and an important factor of relationship commitments (Sirdeshmukh, Singh, \& Sabol, 2002).

Arifin (2016) states that trust has a positive effect on commitment. Also, Moliner, Sánchez, Rodríguez, and Callarisa (2005) suggest that the benevolence dimension of trust has a positive effect on commitment. Similarly, Anderson and Weitz (1992), Nusair, Hua, and Li (2010), Wang, Wang and Liu (2016) and Shin, Chunga, Ohb, and Leec (2013) state that trust has a positive effect on commitment. An inquiry into the relevant literature shows that trust would be an antecedent to commitment ( Aurier \& N'Goala, 2010; Cater \& Zabkar, 2009; Chumpitaz Caceres \& Paparoidamis, 2007; Garbarino \& Johnson, 1999; Geyskens et al., 1996; Kwon \& Suh, 2004; Morgan \& Hunt, 1994; Mukherjee \& Nath, 2007). In banking environments, likewise, trust 
appears to be an antecedent to commitment (Luarn \& Lin, 2003; Sanchez-Franco, 2009; Chung \& Shin, 2010; Arcand, Promtep et al., 2017). We therefore propose:

\section{H5: Trust has a positive effect on commitment in banking services.}

\section{Trust and Satisfaction}

The review of literature shows that trust and satisfaction are two closely intertwined concepts. Most of the empirical studies conducted in different sectors, e.g., online and offline financial services sector, discuss the positive effect of trust on satisfaction (Arcand et al., 2017; Chiou, 2004; Kim, Kim, \& Kandampully, 2009; Lee \& Lin, 2005; Rafiq et al., 2013). Also, an inquiry into the relevant literature shows that trust would be an antecedent to satisfaction ( Chiu \& Wang, 2011; Garbarino \& Johnson, 1999). Arcand et al. (2017) and Kim et al. (2009) argue that in offline and online financial services sector, in particular, trust is the main factor in ensuring satisfaction. Therefore, the next research hypothesis is presented as follows:

\section{H6: Trust has a positive effect on satisfaction in banking services.}

\section{Commitment and Loyalty}

In marketing literature, the concept of commitment is often considered in three different ways: emotional, normative, and computational (Bansal, Irving, \& Taylor, 2004; Cater \& Zabkar, 2009). Commitment has become relevant to researchers and marketers who study online and web-based environments such as online shopping (Ozen, 2015; Park \& Kim, 2003), e-banking (Keating et al, 2011; Mukherjee \& Nath, 2007; Sanchez-Franco, 2009), and banking (Rahman \& Ramli, 2016). Most of these studies have focused on the association between commitment, satisfaction, trust, loyalty, and intention to purchase/repurchase, etc. In marketing research, commitment is an important variable which distinguishes between loyal and non-loyal customers. That is, commitment is the tendency toward continuing a relationship and ensuring its continuity (Rafiq et al, 2013). In their study, Rafiq et al. (2013), Shin, Chunga, Ohb, and Leec (2013), Keating et al. (2011), Ozen (2015), and Rahman and Ramli (2016) show that commitment has a positive effect on loyalty. Therefore, the research hypothesis is presented as follows:

\section{H7. Commitment has a positive effect on loyalty to banking services.}

\section{Satisfaction and Loyalty}

When customers are satisfied with online services, they are more willing to interact with that firm in the future, which results in becoming loyal customers (Fang, Chiu, \& Wang, 2011). The positive relationship between satisfaction and loyalty has been discussed widely in the banking context ( Amin, 2016; Aldas-Manzano, Ruiz-Mafe, Sanz-Blas, \& Lassala-Navarre, 2011; Casalo, Flavian, \& Guinaliu, 2008; Levy, 2014; Sampaio, Ladeira, \& Santini, 2017). Thus, a hypothesis is presented as follows to consider satisfaction:

\section{Hs: Satisfaction has a positive effect on loyalty in banking services.}


Summing up what was mentioned above, the conceptual model of the research is presented in Figure 1.

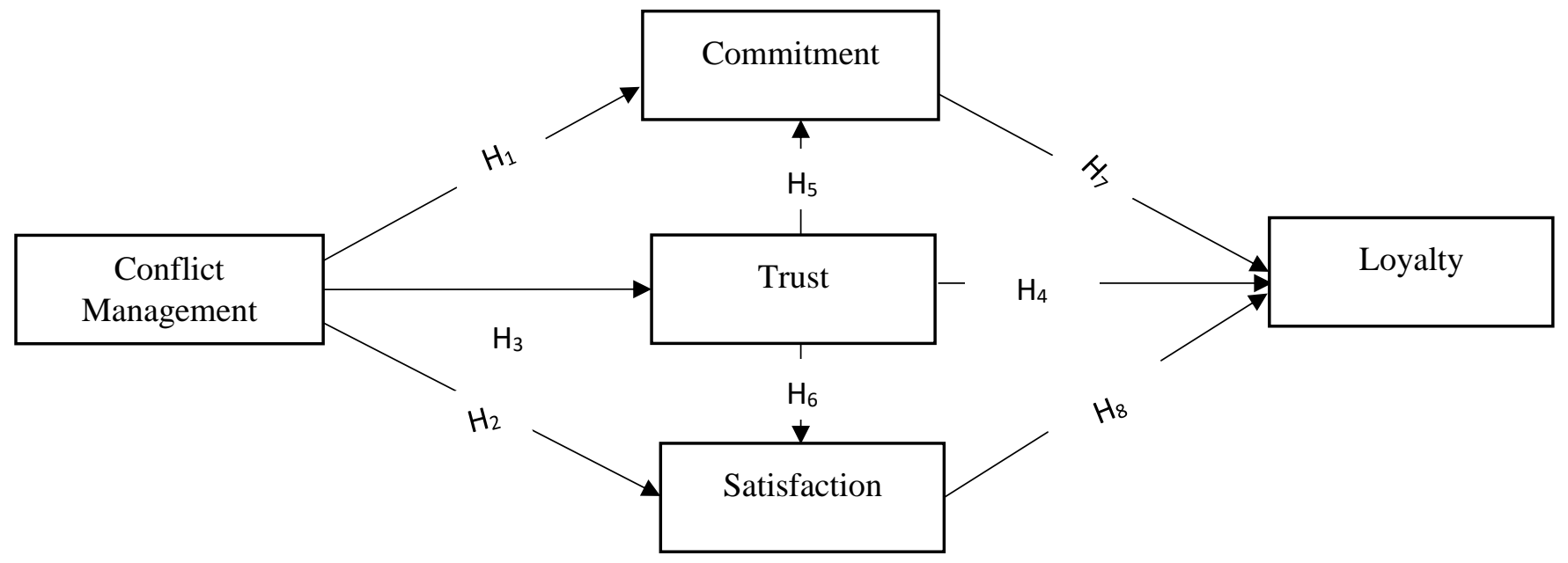

Figure 1. Conceptual model of the research

\section{Method}

\section{Sample and Data Collection}

The questionnaire was finalized once a precise study of the related literature was completed. The bank managers' viewpoints were received and interviews with the bank customers were prepared. As a final step, expertized opinions were received from marketing experts. The aim of this step was to assess the measures exploited in the study. The initial questionnaire was frequently modified and corrected throughout these steps. The revised questionnaire was sent to 500 customers of Iran agriculture banks in East Azarbaijan Province using e-bank services via email, 417 of whom agreed to fill the questionnaire. This rendered a response rate of $83 \%$, which was adequate for using Structural Equation Modeling (SEM). Of the respondents, 74\% were male and $39.4 \%$ were aged between 25 and 34 years old. Table 1 presents the participants' demographic information.

Table 1

Demographic Data

\begin{tabular}{|c|c|c|c|c|}
\hline & & & of Respondents & $\%$ \\
\hline \multirow{2}{*}{ Gender } & \multicolumn{2}{|l|}{ Male } & 286 & 74 \\
\hline & \multicolumn{2}{|l|}{ Female } & 101 & 26 \\
\hline \multirow{6}{*}{ Age } & \multicolumn{2}{|l|}{ Up to 25} & 29 & 7.1 \\
\hline & \multicolumn{2}{|l|}{$25-34$} & 162 & 39.4 \\
\hline & \multicolumn{2}{|l|}{$35-44$} & 156 & 38 \\
\hline & \multicolumn{2}{|l|}{$45-54$} & 62 & 15.1 \\
\hline & \multicolumn{2}{|l|}{$55-64$} & 4 & 1 \\
\hline & \multicolumn{2}{|l|}{$65+$} & 2 & .5 \\
\hline \multirow{4}{*}{$\begin{array}{c}\text { Relationship } \\
\text { duration with bank(years) }\end{array}$} & \multicolumn{2}{|l|}{$1-5$} & 136 & 33.8 \\
\hline & \multicolumn{2}{|l|}{$6-10$} & 132 & 32.8 \\
\hline & $11-20$ & 109 & & 27.1 \\
\hline & $20+$ & 25 & & 6.2 \\
\hline
\end{tabular}




\section{Measurement}

A standardized self-administered questionnaire was developed from an extensive literature review. All the variables used in this research were adopted from the previous studies. A total of 24 scaled items were used to measure the constructs in this model, two items of which were deleted at the stage of evaluating the construct measurement models due to having factor loads below the acceptable level, and 22 items were remained. Table 2 displays the measurement items and research constructs along with their sources. All research constructs were measured using Likert seven-point scale ( strongly disagree $=1$ ) to ( strongly agree $=7$ ).

\section{Analysis Approach}

The data was analyzed using SEM utilizing Amos 23 software, where a 2-step approach was followed (Anderson \& Gerbing, 1988). In the two-phase approach, first the measurement model is processed, and then the structural model is estimated. Each of the constructs under study including conflict management, relationship quality, and customer loyalty, was separately analyzed within a measurement model. The results of confirmatory factor analyses of the constructs showed that Standardized Residual for the item 6 of conflict management was 2.71 that were not within the acceptable level and modification indices also showed that item 3 of conflict management had large values (12.02). Therefore, it was decided to remove these two items. Repeating the confirmatory factor analysis for each of the constructs demonstrated that all the factor loads were above 0.5 , and all the goodness-of-fit indices of the models were placed at an acceptable level. Likewise, the results of confirmatory factor analysis of relationship quality and customer loyalty indicate that the load of all the items were above 0.5 , and the goodness-of-fit indices of the model had acceptable values. Therefore, the value measurement model for relationship quality and customer loyalty were confirmed without any changes. The results of factor load and goodness-of-fit indices for each of the research constructs have been given separately in Table 2.

In order to assess the reliability of the research constructs, we used three methods: Cronbach Alpha, compound reliability (CR), and average variance extracted (AVE). Bagozzi and Yi (1988) argue that the compound reliability should be equal to or higher than 0.6 , the average extracted variance should be equal to or higher than 0.5, and the Cronbach Alpha should be equal to or higher than 0.7. Accordingly, as shown in Table 2, the values of CR, AVE, and Cronbach Alpha are all at the acceptable level. Thus, it can be said that the reliability of the research constructs is at an acceptable level. The constructs showed a high degree of convergent validity since all the AVE values were found to be well above 0.50 (Fornell \& Larcker, 1981).

Moreover, to assess the validity, the square root of AVE was compared to all inter-factor correlation coefficients. As shown in Table 3, the least squares were computed by comparing correlations between each pair of constructs and the square root of the corresponding AVE values of all constructs. 
Table 2

List of the Items and their Sources with Reliability and Dimensionality Indicators

\begin{tabular}{|c|c|c|c|c|}
\hline Constructs and items and their sources & $\begin{array}{c}\text { Factor } \\
\text { Loading }\end{array}$ & $\begin{array}{l}\text { Cronbach's } \\
\text { alpha }(\alpha)\end{array}$ & $\mathrm{CR}$ & AVE \\
\hline \multicolumn{2}{|l|}{ Conflict management: Morgan and Hunt (1994); Anderson and weitz (1992) } & .91 & .81 & .52 \\
\hline The bank is trying to avoid potential disagreement between me and the bank & .69 & & & \\
\hline At this bank, I have never encountered a problem twice & .65 & & & \\
\hline $\begin{array}{l}\text { When the problem arises, the bank can provide clear and rational solutions to the } \\
\text { problem }\end{array}$ & .73 & & & \\
\hline When something goes wrong, the bank's staff will fix it immediately & .79 & & & \\
\hline \multicolumn{5}{|c|}{$\chi^{2}=6.6, \mathrm{df}=2, \mathrm{p}>.03, \mathrm{RMSEA}=.07, \mathrm{NFI}=.98, \mathrm{CFI}=.98, \mathrm{GFI}=.99, \mathrm{AGFI}=.95, \mathrm{TLI}=.96, \chi 2 / \mathrm{df}=3.3$} \\
\hline \multicolumn{5}{|l|}{ Relationship Quality } \\
\hline \multicolumn{2}{|l|}{ Trust: Roberts et al. (2003); Swan et al. (1985); Churchill and Surprenant (1982) } & .86 & .881 & .56 \\
\hline This bank is trustworthy & .77 & & & \\
\hline This bank has always been honest with me & .85 & & & \\
\hline The bank is keeping its promises & .78 & & & \\
\hline The bank's staff rarely make mistakes & .72 & & & \\
\hline \multicolumn{2}{|l|}{ Commitment: Morgan and Hunt (1994); Chen et al. (2011); Roberts et al. (2003) } & .83 & .84 & .65 \\
\hline I plan to maintain a long-term relationship with this bank. & .90 & & & \\
\hline To maintain a relationship with this bank, I need to make more efforts. & .86 & & & \\
\hline I feel emotionally attached to this bank. & .63 & & & \\
\hline Satisfaction: Palmatier (2007); De wulf et al. (2001) & & .90 & .91 & .71 \\
\hline I have a good relationship with this bank & .77 & & & \\
\hline It is a pleasure for me to work with this bank & .88 & & & \\
\hline I am satisfied with this bank & .87 & & & \\
\hline Choosing this bank to cooperate was the right decision & .85 & & & \\
\hline \multicolumn{5}{|c|}{$\chi 2=101.72, \mathrm{df}=41, \mathrm{p}>.001, \mathrm{RMSEA}=.06, \mathrm{NFI}=.96, \mathrm{CFI}=.98, \mathrm{GFI}=.95, \mathrm{AGFI}=.93, \mathrm{TLI}=.97, \chi 2 / \mathrm{df}=2.48$} \\
\hline \multicolumn{2}{|l|}{ Loyalty: Castellanos-Verdugo et al. (2009); De Wulf et al. (2001) } & .96 & .96 & .80 \\
\hline I doubt to change this bank as long as providing services of this bank continues & .85 & & & \\
\hline I prefer using services of this bank to other banks & .91 & & & \\
\hline The first bank that comes to my mind when making a decision is this bank & .90 & & & \\
\hline I intend to use services of this bank in the future & .87 & & & \\
\hline I recommend this bank to others & .92 & & & \\
\hline I encourage friends to use the bank's services & .96 & & & \\
\hline I tell the positive options of e-services of this bank to other people & .83 & & & \\
\hline
\end{tabular}

Table 3

Correlation Matrix and Square Roots of AVES

\begin{tabular}{|c|c|c|c|c|c|}
\hline Construct & Commitment & Loyalty & Satisfaction & Trust & Conflict Management \\
\hline Commitment & .81 & & & & \\
\hline Loyalty & .50 & .89 & & & \\
\hline Satisfaction & .49 & .59 & .84 & & \\
\hline Trust & .53 & .60 & .52 & .74 & \\
\hline Conflict Management & .66 & .54 & .61 & .52 & .72 \\
\hline
\end{tabular}

Notes: The numbers in the diagonal are the square root of AVE. 


\section{Results}

Table 4 and Figure 2 illustrate the hypothesized relationships and summarize the hypotheses supported by the results. All the hypotheses were supported. The goodness-of-fit indices demonstrated that this model fitted the data adequately even though a significant chi-square was obtained $(\chi 2=13.51, d f=5, p=.01, \mathrm{~N}=417)$. Since the likelihood ratio statistic based on chisquare is known to be sensitive to the sample size (Byrne, 2001), a relative chi-square statistic $(\chi 2 / \mathrm{df})$ is increasingly used as a measure of fit. The value of $\chi^{2 / \mathrm{df}}$ in this study was found to be 2.70, which was lower than the acceptance limit of 5 (Hair, Anderson, Tatham, \& Black, 1995). The GFI, AGFI, NFI, CFI, TLI, and RSMEA were 0.98, 0.95, 0.99, 0.99, 0.98, and 0.06, respectively.

Table 4

Testing the Hypotheses Using the Standardized Estimates

\begin{tabular}{llccccc}
\hline & Hypothesized Path & SE & $\begin{array}{c}\text { Std. } \\
\text { estimate }\end{array}$ & t-value & $p$ & Supported \\
\hline $\mathrm{H}_{1}$ : Conflict Management & $\longrightarrow$ Commitment & .04 & .53 & 12.88 & .000 & YES \\
$\mathrm{H}_{2}$ : Conflict Management & $\longrightarrow$ Satisfaction & .05 & .46 & 10.54 & .000 & YES \\
$\mathrm{H}_{3}$ : Conflict Management & Trust & .04 & .52 & 12.72 & .000 & YES \\
$\mathrm{H}_{4}:$ Trust & Loyalty & .07 & .43 & 9.38 & .000 & YES \\
$\mathrm{H}_{5}:$ Trust & Commitment & .04 & .25 & 6.23 & .000 & YES \\
$\mathrm{H}_{6}:$ Trust & Satisfaction & .05 & .28 & 6.46 & .000 & YES \\
$\mathrm{H}_{7}:$ Commitment & Loyalty & .06 & .16 & 4.09 & .000 & YES \\
$\mathrm{H}_{8}:$ Satisfaction & Loyalty & .05 & .31 & 7.51 & .000 & YES \\
\hline
\end{tabular}

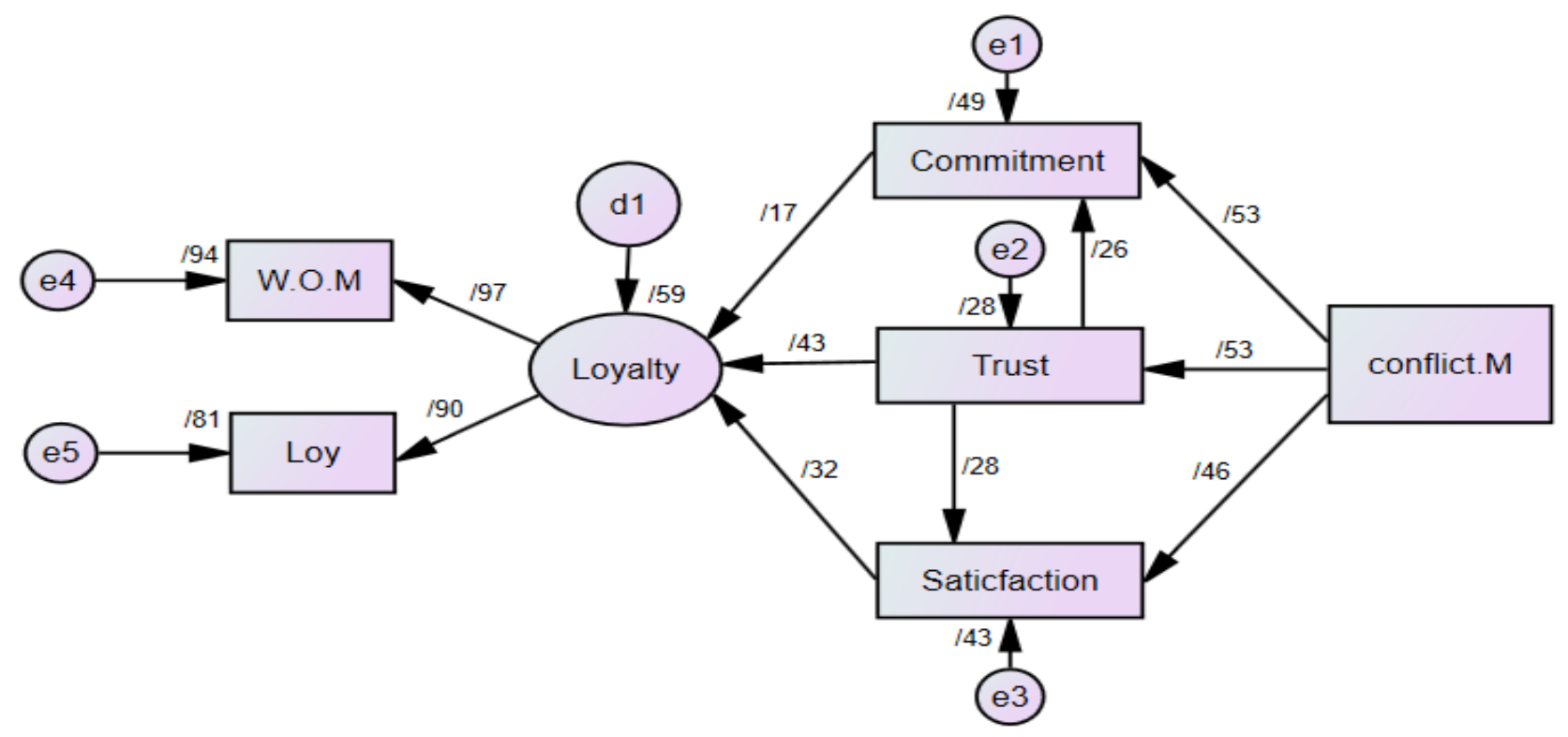

Figure 2. Results of the hypothesized structural equation model 
The results of the structural model indicated that 8 paths were significant at $p<.001$. The test of the structural model indicated that conflict management has a positive impact on commitment $(\beta=.53, p<.001)$, satisfaction $(\beta=.46, p<.001)$ and trust $(\beta=.52, p<.001)$. It was also found that trust has a positive impact on loyalty $(\beta=.43, p<.001)$, commitment $(\beta=.25 p<.001)$ and satisfaction $(\beta=.28, p=.001)$. In addition, the results showed that commitment $(\beta=.16, p<.001)$ has positive effect on customer loyalty in banking services; also, customer satisfaction in banking services has a positive effect on customer loyalty $(\beta=.31, p<.001)$.

\section{Discussion and Managerial Implications}

This study highlighted the role of organizational leadership in improving customer relationships and enhancing customer loyalty through conflict management between company employees and customers. The results demonstrated that the conflict management has a positive effect on the three dimensions of relationship quality (trust, commitment, and satisfaction). Furthermore, the results showed that the relationship quality dimensions (commitment, satisfaction, and trust) have a positive effect on customer loyalty.

The results indicate that customers will remain loyal to banking services only when they evaluate the quality of relationship is desirable and when the banks can establish a suitable relationship with the customers through the use of conflict management strategy. Customers consider desirable a relationship that they can trust, the two parties are committed to and are satisfied with. These results are in line with those obtained by Shin et al. (2013), Park, Lee, and Lee (2014), Aurier and N'Goala, (2010), and Polites, Williams, Karahanna, and Seligman, (2012).

The results gained by Arcand et al. (2017) revealed that in financial services sector, trust is the main factor to guarantee customer satisfaction and commitment; the present research, too, shows that in banking services, trust in relationship is considered to be the antecedent to satisfaction and commitment. That is, with the increase in customer trust, satisfaction and commitment of the customers to services also increase.

On the whole, this result, along with the few previous findings, points out that conflict management, as one of the basic elements of relationship marketing plays an essential part in maintaining the relationship with customers in the long run.

These findings could be of benefit for the service companies that understand the importance of different investments for the customers in gaining the highest rate of customer loyalty. Therefore, if a company seeks to make optimum use of its resources, it should put on its agenda the strategy of conflict management to improve customer relationships and enhance customer loyalty. Purchase behavior will be reinforced and the customers' relation with the company will develop and enter the buildup stage. According to the customer engagement marketing theory (Pansari \& Kumar, 2017), if a customer receives services that lead to his/her satisfaction, it is very likely that his/her relationship with company will be sustained, the relationship life value will increase, and the customer will maintain his/her relationship with the company. If the initial experiences in a relationship are pleasant and positive (not conflict) and if the relation leads to desirable outcomes besides there being evidence of dependability in it, the two parties will proceed to deepen and 
develop the relationship through increasing the overall level of mutual dependence, and the satisfied customers will use references in order to introduce new customers to the company.

This study was also confronted with some limitations as follows: Sheth and Parvatiyar (2000) express that different culture affect customers' attitude towards relationships. Therefore, the caution should be taken for generalizability of the results toward other cultures. The results of this study reflect the Iranian customer's perspective and it is recommended to carry out this research in other developing countries.

Another limitation of the research is statistical sample selection. Statistical sample of the research is limited to customers with a current account in bank and other customers with deposit accounts and thus other accounts were not considered in statistical society. Thus, for the generalizability of the results to all bank customers in banking industry should be cautious and it is recommended to conduct similar studies with larger statistical society customers including customers with bank accounts in order to replicate more reliable results that can be generalized to the entire Iranian banking industry customers.

\section{References}

Aldas-Manzano, J., Ruiz-Mafe, C., Sanz-Blas, S., \& Lassala-Navarré, C. (2011). Internet banking loyalty: evaluating the role of trust, satisfaction, perceived risk and frequency of use. The Service Industries Journal, 31(7), 1165-1190.

Amin, M. (2016). Internet banking service quality and its implication on e-customer satisfaction and e-customer loyalty. International Journal of Bank Marketing, 34(3), 280-306,

Anderson, J. C., \& Gerbing, D. W. (1988). Structural equation modeling in practice: A Review and recommended two-step approach. Psychological Bulletin, 103(3), 411-423.

Anderson, J. C., \& Weitz, B. (1992). The use of pledges to build and sustain commitment in distribution channels. Journal of Marketing Research, 29(1), 18-34.

Arcand, M., Promtep, S., Brun, I., \& Rajaobelina, L. (2017). Mobile banking service quality and customer relationships. International Journal of Bank Marketing, 35(7), 1068-1089.

Arifin, M. (2016). Impact of e-banking user behavior to loyalty. International Journal of Business and Management Invention, 5(1), 90-97

Aurier, P., \& N'Goala, G. (2010). The differing and mediating roles of trust and relationship commitment in service relationship maintenance and development. Journal of the Academy of Marketing Science, 38(3), 303-325.

Bagozzi, R. P., \& Yi, Y. (1988). On the evaluation of structural equation models. Journal of The Academy of Marketing Science, 16(1), 74-94.

Bansal, H. S., P. Irving, P. G., \& Taylor, S. F. (2004). A three-component model of customer commitment to service providers. Journal of the Academy of Marketing Science, 32(3), 234-250.

Berry, L. L., \& Parasuraman, A. (1991). Marketing services: Competing through quality. New York: The Free Press.

Bilgihan, A., \& Bujisic, M. (2014). The effect of website features in online relationship marketing: a case of online hotel booking. Electronic Commerce Research and Applications, 14(4), 222-232,

Birjandi, M., Gholami, A., Haghighi, M. (2018). Creating utilitarian and hedonic Purchasing Values on satisfaction and loyalty to Shopping Centers (case study: Shiraz hyperstar). Journal of Strategic Management Studies, 9(35), 101-119.

Byrne, B. M. (2001). Structural equation modelling with Amos: Basic concepts, applications, and programming. Mahwah, NJ: Erlbaum. 
Caceres, I., \& Paparoidamis V. (2007). Service quality, relationship satisfaction, trust, commitment and business to business loyalty. European journal of Marketing, 19, 54-61.

Casalo, L.V., Flavián, C., \& Guinalíu, M. (2008). The role of satisfaction and website usability in developing customer loyalty and positive word-of-mouth in the e-banking services. International Journal of Bank Marketing, 26(6), 399-417.

Castellanos-Verdugo, M., Oviedo-Garcia, M. A., Roldan, J. L., \& Veerapermal, N. (2009). The employee-customer relationship quality: Antecedents and consequences in the hotel industry. International Journal of Contemporary Hospitality Management, 21(3), 251-274.

Cater, B., \& Zabkar, V. (2009). Antecedents and consequences of commitment in marketing research services: the client's perspective. Industrial Marketing Management, 38(7), 785-797.

Chang, H., H., \& Wang, H., W. (2011). The moderating effect of customer perceived value on online shopping behavior. Online Information Review, 35(3), 333-359.

Chang, H. H., Wang, Y. H., \& Yang, W. Y. (2009). The impact of e-service quality, customer satisfaction and loyalty on emarketing: Moderating effect of perceived value. Total Quality Management and Business Excellence, 20(4), $423-443$.

Chen, C., F., \& Wang, J., P. (2016). Customer participation, value co-creation and customer loyalty e A case of airline online check-in system. Computers in Human Behavior, 62, 346-352.

Chen, C. Y., Chen, C. C., Chen Y. S., \& Wey, S. C. (2011). Moderating effects in relationship marketing: The roles of customer expertise and price orientation. African Journal of Business Management, 5(22), 9490-9502

Chen, S., C. (2012). The customer satisfaction-loyalty relation in an interactive e-service setting: The mediators. Journal of Retailing and Consumer Services, 19, 202-210.

Chiou, J. S. (2004). The antecedents of consumers' loyalty toward Internet Service Providers. Information and Management, 41(16), 685-695.

Chumpitaz Caceres, R., \& Paparoidamis, N.G. (2007). Service quality, relationship satisfaction, trust, commitment and businessto-business loyalty. European Journal of Marketing, 41(7/8), 836-867.

Chung, K., H., \& Shin, J., I. (2010). The antecedents and consequents of relationship quality in internet shopping. Asia Pacific Journal of Marketing and Logistics, 22(4), 473-491.

Churchill, G. A., \& Surprenant, C. (1982) An investigation into the determinant of customer satisfaction, Journal of Marketing Research, 19(4), 491-504.

Clemes, M., Mollenkopf, D., \& Burn, D. (2010). An investigation of marketing problems across service typologies. Journal of Services Marketing, 14(7), 573-594.

Deutsch, M. (2001), Cooperation and conflict resolution: Implications for consulting psychology. Consulting Psychology Journal: Practice and Research, 53(2), 76-81.

De Wulf, K., Odekerken-Schroder, G., \& Iacobucci, D. (2001). Investments in consumer relationships: a cross-country and crossindustry exploration. Journal of Marketing, 65(4), 33-50.

Doney P. M, \& Cannon, J. P. (1997). An examination of the nature of trust in buyer-seller relationships. Journal of Marketing, 61(2), 35-51.

Dwyer, F. R., \& Oh, S. (1987). Output sector munificence effects on the internal political economy of marketing channels. Journal of Marketing Research, 24(4), 347-358.

Elbeltagi, I. \& Agag, G. (2016). E-retailing ethics and its impact on customer satisfaction and repurchase intention. Internet Research, 26(1), 288-310.

Fang, J, Shao, Y., \& Wen, C. (2016). Transactional quality, relational quality, and consumer e-loyalty: Evidence from SEM and fsQCA. International Journal of Information Management, 36(6), 1205-1217.

Fang, Y., Chiu, C., \& Wang, E. T. G. (2011). Understanding customers' satisfaction and repurchase intentions. Internet Research, 21(4), 479-503. 
Fornell, C., \& Larcker, D. F. (1981). Evaluating structural equation models with unobservable variables and measurement error. Journal of Marketing Research, 18(1), 39-50

Garbarino, E., \& Johnson, M. S. (1999). The different roles of satisfaction, trust, and commitment in customer relationships. Journal of Marketing, 63(2), 70-87.

Geyskens, I., Steenkamp, J. E. M., Scheer, K. L., \& Kumar, N. (1996). The effects of trust and interdependence on relationship commitment: a trans-Atlantic study. International Journal of Research in Marketing, 13(4), 303-317.

Grabner-Krauter, S., \& Kaluscha, E. A. (2003). Empirical research in on-line trust: A review and critical assessment. International Journal of Human-Computer Studies, 58(6), 783-812.

Hair, J. F., Anderson, R. E., Tatham, R., \& Black, W. (1995). Multivariate data analysis with readings. Englewood Cliffs, NJ: Prentice-Hall.

Hoffman, D. L., Novak, T. P., \& Peralta, M. (1999). Building consumer trust online. Communications of the ACM, 42(4), 80-85.

Keating, B. W., Alpert, F., Kriz, A., \& Quazi, A. (2011). Mediating role of relationship quality in online services. Journal of Computer Information Systems, 52(2), 33-41.

Kim, J. H., Kim, M. J., \& Kandampully, J. (2009). Buying environment characteristics in the context of e-service. European Journal of Marketing, 43(9/10), 1188-1204.

Kim, W. G., Lee, Y., \& Yoo, Y. (2006). Predictors of relationship quality and relationship outcomes in luxury restaurants. Journal of Hospitality and Tourism Research, 30(2), 143-169.

Kwon, I. G., \& Suh, T. (2004). Factors affecting the level of trust and commitment in supply chain relationships. The Journal of Supply Chain Management, 40(2), 4-14.

Lattimore, K., (2011). The antecedents of relationship quality in Canada and united states. Journal of Service Marketing, 12(13), 177-194.

Lee, G. G., Lin, H. F. (2005). Customer perceptions of e-service quality in online shopping. International Journal of Retail and Distribution Management, 33(2), 161-176.

Levy, S. (2014). Does usage level of online services matter to customers' bank loyalty? Journal of Services Marketing, 28(4), 292-299.

Lichtenstein, S., \& Williamson, K. (2006). Understanding consumer adoption of internet banking: an interpretive study in the Australian banking context. Journal of Electronic Commerce Research, 7(2), 50-66.

Luarn, P., \& Lin, H. H. (2003). A customer loyalty model for e-service context. Journal of Electronic Commerce Research, 4(4), 156-167.

Moliner, M. A., Sánchez, J., M. Rodríguez, R., \& Callarisa, L. (2005). Perceived relationship quality and post-purchase perceived value: An integrative framework. European Journal of Marketing, 41(11), 1392-1422.

Morgan, R, M., \& Hunt, S, D. (1994). The commitment-trust theory of relationship marketing. Journal of Marketing, 58(3), 2038.

Mukherjee, A., \& Nath, P. (2007). Role of electronic trust in online retailing A re-examination of the commitment-trust theory. European Journal of Marketing, 41(9/10), 1173-1202.

Naoui, F. B., \& Zaiem, I. (2010). The impact of relationship quality on client's loyalty: An application in the parapharmaceutical industry. International Journal of Pharmaceutical and Healthcare Marketing, 4(2), 137-156.

Ndubisi, N. O. (2007). Relationship marketing and customer loyalty. Marketing Intelligence and Planning, 25(1), 98-106

Nusair, K., K., Bilgihan, A., Okumus, F., \& Cobanoglu, C. (2013). Generation Y travelers' commitment to online social network websites. Tourism Management, 35, 13-22.

Nusair, K., K., Hua, N., \& Li, X. (2010). A conceptual framework of relationship commitment: e-travel agencies. Journal of Hospitality and Tourism Technology, 1(2), 106-120. 
Ozen, H. (2015). Online relationship quality: Does it increase repurchase intention from private shopping sites? International Journal of Academic Research in Business and Social Sciences, 5(7), 300-312.

Palmatier, R. W. (2007). What Drives Customer Relationship Value in Business-to-Business Exchanges? Marketing Science Institute Report, 4, 07-118.

Palmatier, R. W. (2008). Interfirm Relational Drivers of Customer Value. Journal of Marketing, 72(4), 76-89.

Palmatier, R. W. (2009). Relationship marketing. Cambridge, Massachusetts: Marketing Science Institute.

Palvia, P. (2009). The role of trust in e-commerce relational exchange: A unified model. Information and Management, 46(4), 213-220.

Pansari, A., \& Kumar, V. (2017). Customer engagement: The construct, antecedents, and consequences. Journal of the Academy of Marketing Science, 45(3), 294-311.

Papassapa, R., \& Miller, K. E. (2007). Relationship quality as a predictor of B2B customer loyalty. Journal of Business Research, $60(1), 21-31$.

Park, C., \& Kim, Y. (2003). Identifying key factors affecting consumer purchase behaviour in an online shopping context. International Journal of Retail and Distribution Management, 31(1), 16-29.

Park, J. G., Lee, S., \& Lee, J. (2014). Communication effectiveness on IT service relationship quality. Industrial Management and Data Systems, 114(2), 321-336.

Pengnate, S., \& Sarathy, R. (2017). An experimental investigation of the influence of website emotional design features on trust in unfamiliar online vendors. Computers in Human Behavior, 67, 49-60.

Polites, G. L., K. Williams, C. K, Karahanna, E., \& Seligman, L. (2012). A Theoretical framework for consumer e-satisfaction and site stickiness: An evaluation in the context of online hotel reservations. Journal of Organizational Computing and Electronic Commerce, 22(1), 1-37.

Rafiq, M., Fulford, H., \& Lu, X. (2013). Building customer loyalty in online retailing: The role of relationship quality. Journal of Marketing Management, 29(3-4), 494-517.

Rahman, M., A., \& Ramli, M., F. (2016). The influence of relationship quality on customer loyalty in the dual-banking system in the northern states of peninsular Malaysia. Procedia - Social and Behavioral Sciences, 219(31), 606-613.

Rexha, N., Kingshott, R. P. J., \& Aw, A. S. S. (2003). The impact of the relational plan on adoption of electronic banking. Journal of Services Marketing, 17(1), 53-67.

Roberts, K., Varki, S., \& Brodie, R. (2003). Measuring the quality of relationships in consumer services: an empirical study. European Journal of Marketing, 37(1/2), 169-196.

Sahney, S., Ghosh, K., \& Shrivastava, A. (2013). Conceptualizing consumer "trust" in online buying behaviour: an empirical inquiry and model development in Indian context. Journal of Asia Business Studies, 7(3), 278-298.

Salim, N. A. (2011). The evaluation of relationship marketing of skin care services at PKU Muhammadiyah Yogyakarta Hospital. Journal Kesehatan Komunitas, 2(3), 122-127.

Sampaio, C. H., Ladeira, W. J., \& Santini, F. D. O. (2017). Apps for mobile banking and customer satisfaction: a cross-cultural study. International Journal of Bank Marketing, 35(7), 1133-1153.

Sanchez-Franco, M. J. (2009). The moderating effects of involvement on the relationships between satisfaction, trust and commitment in e-banking. Journal of Interactive Marketing, 23(3), 247-258.

Sheth, J.N. and Parvatiyar, A. (2000) 'The evolution of relationship marketing', in Sheth, J.N. and

Parvatiyar, A. (Eds.):

Handbook of Relationship Marketing, pp.119-148, Sage, London.

Sheth, J. N., \& Parvatiyar, A. E. (2000). The evolution of relationship marketing. In J. N. Sheth \& A. E. Parvatiyar (Eds.), Handbook of relationship marketing (pp. 119-148). London: sage. 
Shin, J., I., Chunga, K., H., Ohb, J., S., \& Leec, C., W. (2013). The effect of site quality on repurchase intention in Internet shopping through mediating variables: The case of university students in South Korea. International Journal of Information Management, 33(3), 453-463.

Sirdeshmukh, D., Singh, J., \& Sabol, B. (2002). Consumer trust, value, and loyalty in relational exchanges. Journal of Marketing, $66(1), 15-37$.

Suh, B., \& Han, I. (2002). Effect of trust on customer acceptance of Internet banking. Electronic Commerce Research and Applications, 1(3-4), 247-263.

Swan, J. E., Trawick, I. F., \& Silva, D. W. (1985). How industrial salespeople gain customer trust. Industrial Marketing Management, 14(3), 203-211.

Sweeney, B., \& Pierce, B. (2004). Management control in audit firms: A qualitative examination. Accounting, Auditing and Accountability Journal, 17(5), 779-812.

Wang, W. T., Wang, Y. S., \& Liu, E. R. (2016). The stickiness intention of group-buying websites: The integration of the commitment-trust theory and e-commerce success model. Information and Management, 53, 625-642.

Yamagishi, T., \& Yamagishi, M. (1994). Trust and commitment in the United States and Japan. Motivation and emotion, 18(2), 129-166.

Yang, L., \& Capel J. (2011). The antecedents of relationship quality in Malaysia and New Zealand. Journal of Economic Psychology, 10, 363-389.

Yavas, D., Ennew, C. T., \& Palmer, A. (2004). Trust, ethics and relationship satisfaction. International Journal of Bank Marketing, 16(4), 170-175. 